\title{
The perversion of virtue. Understanding murder-suicide
}

\author{
Anmeldt av Kim Larsen
}

Understanding Murder-Suicide

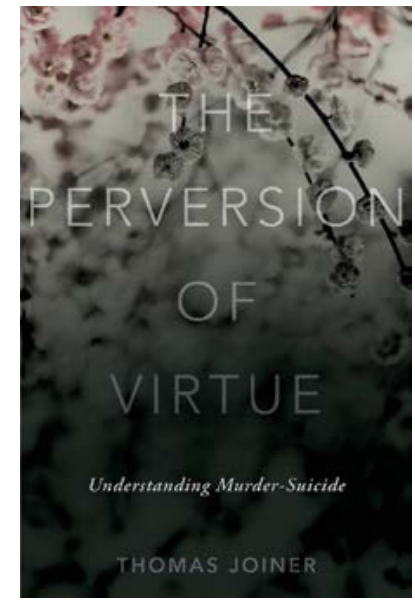

THOMAS JOINER

The perversion of virtue.

Understanding murder-suicide

Oxford University Press, 2014

254 sider

ISBN: 978-0-19-933455-1

\section{DE MEST HJERTESKJÆRENDE} selvmordsrelaterte mediereportasjene er saker hvor for eksempel en far dreper sin familie eller sin ekskone og eventuelt hennes nye kiæreste og deretter utfører selvmord. Mord-selvmord er heldigvis sjeldent. I USA er det estimert en rate på o,25 (tilfeller pr. 100 o०o). Dette er som forventet ut fra amerikansk mordstatstikk høyere enn giennomsnittet i resten av verden, hvor det er estimert til en rate på o,15. To prosent av alle selvmord i USA er mord-selvmord. Når det gielder mord er 75 prosent av ofrene menn, mens for mordselvmord er 75 prosent av de som blir myrdet kvinner. Mordselvmord har en større overvekt av menn som gierningspersoner enn både mord og selvmord separat; 90 prosent av de som utfører mordselvmord er menn.

Som tittelen gir uttrykk for, ser Ioiner mord-selvmord som resultat av en pervertert oppfatning av i utgangspunktet høyverdige verdier; barmhjertighet, rettferdighet, pliktfølelse og heroisme. Et eksempel kan være en far som står i fare for å miste omsorgsretten og som myrder sine barn og deretter utfører selvmord, og som i et selvmordsbrev forklarer at han har «reddet dem fra å lide i en fiendtlig verden og fra å falle i hendene på moren og hennes terrorregime». En slik pervertert logikk, i dette tilfellet av verdien «barmhjertighet», har ofte selvmordet som forutsetning og utleder at gitt selvmordet vil barnas situasjon være slik at døden er å foretrekke, ifølge gierningsmannen. En variant med perversion av verdien rettferdighet er ofte mord på mannens ekskone (og eventuelt dennes nye mann), eller også mord-selvmord på arbeidsplasser/skoler hvor man hevner seg for angivelige oppakkumulerte urettferdigheter.

Forfatterens plan med boken er å «take us on a journey that involves understanding murder

\section{Toiner ser selvmord} som det primære i mordselvmord og mener at selvmordsforebygging også er mord-selvmordsforebygging

per se, suicide per se, their convergence in often horrible incidents of murder-suicide, the essence and types of virtue, and crucially, how the perversion of virtue is the sine qua non of genuine murdersuicide» (s. 5, uthevinger i originalen). Boken er delt inn i tre deler. I del én får vi en innledning med definisjoner og beskrivelser av forskjellige typer mord-selvmord og opplysninger om utbredelsen, og deretter ett kapittel hver om mord, selvmord og verdier («virtues»). I del to analyserer og fortolker Joiner ved hjelp av teori og forskning detaljerte eksempler på saker som involverer mord-selvmord, relatert til de verdiene jeg nevnte innledningsvis. I del tre beskriver han hvilke implikasjoner han mener sitt perspektiv vil kunne ha i klinisk praksis.

Joiner ser selvmord som det primære i mord-selvmord og mener at selvmordsforebygging også er mord-selvmordsforebygging. Han hevder på bakgrunn av dette at en derfor i enhver selvmordsrisikovurdering også bør kartlegge personens risiko for og tilbøyelighet til vold mot andre, samt også vurdere personens opptatthet av perverterte versioner av de nevnte verdier. Men, hvordan kan en giøre dette uten at det blir et gigantisk malapropos i den kliniske situasjonen? Et eksempel på tilnærming overfor 
en pasient som ikke samarbeider i et interviu er følgende: «It appears to me that something is on your mind, but I see that you don't want to talk about problems. Let's shift gears then and change the topic altogether. What if we talked for a while about the positive? In particular, I would be interested to know your views on positive qualities like honor, justice, mercy, duty, and heroism» (s. 198-199). Denne delen om å la selvmordsrisikovurderinger også inneholde en voldsrisikovurdering, selv om den følger av Joiners system, vil lett kunne innebære å blåse nytt liv i forestillingen om selvmord som primært knyttet til aggressive motiver (Menninger, 1938). Det er ingen tvil om at det finnes selvmord med markante aggressive islett, men jeg vil mene at Shneidman (1985; 1993) har mer rett når han hevder at det mest typiske emosjonelle landskap ved selvmord ikke er aggresion, men mer maktesløse emosioner som fortvilelse, angst, håpløshet, meningsløshet, etc. Dette er Joiner selv også enig i, men det at den kliniske undersøkelse av selvmordsrisiko også alltid skal inneholde en kartlegging av aggresion mot andre, vil i praksis bidra til å etablere en forestilling om en knytning mellom selvmord og aggresion.

Av nåtidige suicidologiske teoretikere har jeg en oppfatning av Ioiner som den som er mest forelsket i sin egen teori og som derved går inn i en slags fortolkningsmessig overdrivelse når han skal fremstille teori og forskning i det øvrige suicidologiske fagfeltet; noe à la det man i attribusionspsykologien kaller bekreftelsesstrategier. Nå er det slett ikke uvanlig i vitenskapen å favorisere sin egen teori (det er påfallende få eksempler på at en som har sammenlignet forskjellige psykoterapisystemer har kommet til den konklusjonen at hans eget system ikke er best), men etter min mening legger Joiner inn et ekstra gir på dette området. Etter å ha lest alle Joiners bøker mener jeg også å se en utvikling her. Den første boken Why people die by suicide (2005) er mer undrende og åpen i

\section{Av nåtidige suicidologiske teoretikere har jeg en oppfatning av Joiner som den som er mest forelsket $i$ sin egen teori}

formen, men via Myths about suicide (2010) og Lonely at the top: The high cost of men's success (2011) til den foreliggende bok virker det som Joiner blir suksessivt mer sikker på fortreffeligheten av sin egen teori om at de primære motiver bak selvmord er en opplevelse av å være en byrde ("perceived burdensomeness») og manglende tilhørighet («twarted belongingness»), kombinert med oppøvet evne til å påføre seg selv alvorlig skade. Han kan fastslå som sannheter og entydigheter forhold som er mye omdiskutert i suicidologien. Viktige eksempler er hans påstander om at: A. 100 prosent av selvmordene skyldes psykisk lidelse. (Der det ikke oppfattes slik, er det fordi det dreier seg om subkliniske manifestasioner som omgivelsene ikke oppfatter). B. Personer som utfører selvmord har vanligvis ikke alkohol i blodet. C. Selvmord er ikke impulsive. (De oppfattes bare slik. Joiner bruker her meteoritten som metafor: Den virker overraskende akkurat i det den treffer jorden, men før dette har den brukt lang tid på sin ferd; det er bare den siste delen som virker overraskende.) Disse tre viktige momentene er alle forhold som er mye omdiskutert i suicidologien, men det hopper Joiner lett over.

Når jeg leser Joiner, får jeg en beklemmende følelse av at han presser teori og empiri inn i sitt kategorisystem på en anstrengt og Prokrustes-aktig måte, samt også utelater relevant teori og empiri som ikke passer inn uten at han kommenterer det. La oss ta et enkelt eksempel som illustrasjon: Joiner argumenterer slik om sammenhengen mellom egoisme, selvmord og psykopati: «People with psychopathy (a callous, uncaring, deeply irresponsible attitude toward others) are, of all the people with mental disorders, the most selfish. If suicide were about selfishness, it would then follow that psychopaths would have quite high rates of suicide. But they have among the lowest» (s. 93). Han gir ingen referanse til forskning. I stedet henvises det til en påstand $\mathrm{i}$ Hervey Checkleys bok The mask of sanity (1941). Denne argumentasionen er typisk Ioiner; i et empirisk spørsmål hvor han kunne ha referert til forskning, glipper han unna ved å henvise til en ubegrunnet påstand som kilde.

Vil dette si at boken er verdiløs? Neppe. Heldigvis har Joiner et visst metaperspektiv og medgir at hans konseptualisering av mord-selvmord er noe spekulativ. Dessuten er det så lite litteratur om dette dypt tragiske feltet at selv rudimentære og spekulative bøker er velkomne ved at de kan sette temaet på dagsorden og ha en heuristisk funksjon ved å generere forskning og teori. The perversion of virtue. Understanding murder-suicide må imidlertid leses både med et kritisk blikk og med grundig kunnskap om suicidologisk teori og forskning slik at en ikke blir offer for forfatterens ensidige fremstilling, og kan avsløre hvilke snarveier han tar i fremstillingen av suicidologisk teori og forskning for å få den til å passe med sine teoretiske kiepphester.

\section{REFERANSER}

Checkley, H. (1941). The mask of sanity. St. Louis: Mosby.

Joiner, T. (2005). Why people die by suicide. London: Harvard University Press.

Ioiner, T. (2010). Myths about suicide. London: Harvard University Press.

Joiner, T. (2011). Lonely at the top. The high cost of men's success. London: St. Martin's Press.

Menninger, K. (1938). Man against himself. London: Harcourt Brace Jovanovich.

Shneidman, E. (1985). Definition of suicide. New York: Regina Ryan.

Shneidman, E. (1993). Suicide as psychache. A clinical approach to self-destructive behavior. London: Jason Aronson. 